\title{
REFERENCES:
}

1. Biazliepkina, A. (2012). 100 sloŭ pra sučasnuju bielaruskuju litaraturu (in Bel.)

2. Chadanovič A. (2019). Hateĺ Bielaruś, available at: https://www.youtube.com/watch?v=XG2R5LEAp9U\&list=LLX0vBwZzCAv17XUn7M mlymw\&index $=6 \& \mathrm{t}=0 \mathrm{~s}$

3. Chadanovič, A. (2004). Listy z-pad koŭdry (in Bel.).

4. Chadanovič, A. (2015). Ciahnik Čykaha - Tokijo (in Bel.).

5. Chadanovič, A. (2015). Natatki tatki (in Bel.).

6. Irvanets, O. (2002). Khadanovych z-pid kovdry. Ukraina moloda, 08.11, available at: http://dzvinkaxxv.narod.ru/etsirvan.htm

7. Irvanets, O., Khadanovich, A. (2018). Vechir poezii, available at: https://www.youtube.com/watch?v=XG2R5LEAp9U\&list=LLX0vBwZzCAv17XUn7M mlymw\&index $=6 \& \mathrm{t}=0 \mathrm{~s}$

8. Khadanovich A. (2015) Biloruskyi muzhchyna (in Ukr.).

9. Khadanovych, A. (2002). Lysty z-pid kovdry (in Ukr.).

10. Khadanovych, A. (2011). Tatkovi notatky. (in Ukr.).

11. Skarapanava, I. S. (2011). Limeryki Andreja Chadanoviča. Chtenie: retseptsiya i interpretatsiya, 2, 69-76 (in Bel.).

12. Žadan, S. (2015). Ukrainskija avijalinii: vybranyja vieršy (in Bel.).

Карацуба М.Ю. к.філол.н., доц., Інститут мистецтвознавства, фольклористики та етнологї імені М.Т. Рильського НАН Украӥни

Karatsuba M.

PhD, Associate Professor, Institute of Art Studies, Folklore Studies and Ethnology named after M. T. Rylsky National Academy of Sciences of Ukraine

\author{
МОТИВ ПЕРЕТВОРЕННЯ ЯК ОДИН 3 КЛЮЧОВИХ \\ МОТИВІВ НАРОДНОЇ БАЛАДИ ПІВДЕННИХ СЛОВ'ЯН
}

\section{MOTIV OF TRANSFORMATION AS ONE OF THE KEY MOBITES OF THE PEOPLE BALADE OF THE SOUTH SLOVENIAN}

У запропонованій статті аналізується один із найпоказовіших мотивів, представлених у народних баладах південних слов'ян - мотив перетворення. У вступній частині аргументується важливість звернення до розгляду иьього 
мотиву для розуміння жанру народної балади в цілому та специфіки ї̈ побутування на південнослов'янських теренах, зокрема. Об'єктом дослідницької уваги виступають сербські, хорватські, македонські, болгарські, боснійські народні балади - усі тексти, де присутній мотив перетворення, $і$ де він має важливе змістове значення.

Ключові слова: перетворення, метаморфоза, безсмертя душі, фантастичний первень, народна балада.

The proposed article analyzes one of the most representative motifs presented in folk ballads of the Southern Slavs - the motive of transformation. The introductory part argues the importance of applying for consideration of this motive for understanding the genre of the folk ballad in general and the specifics of its existence in the South Slavic territories, in particular. The subject of research attention is Serbian, Croatian, Macedonian, Bulgarian, Bosnian folk ballads - all texts where there is a motive of transformation, and where it has an important meaning. This question is not fundamentally new, as domestic as well as foreign researchers have already turned to certain aspects of the functioning of the motive of transformation in folk ballads. Among researchers from the South Slavic area to this issue practiced almost all the more and less well-known scholars, in the focus of their attention were, however, some varieties of transformations-metamorphosis or their purpose in the context of understanding the ballad text. Despite the general didactic guideline for which the motive is involved in a whole array of ballad texts, the circumstances in which it is used are completely different. The author below aims to demonstrate to what types of metamorphosis we encounter the folk ballads of the Southern Slavs. The author, undoubtedly, stops only at certain episodes of the functioning of the motive of transformation, tracking it on examples from the collections of ballads of individual peoples.

Key words: transformation, metamorphosis, immortality of the soul, fantastic liter, folk ballad.

Перетворення (грецькою - метаморфоза) відносимо до дуже давніх міфологічних уявлень, які яскраво представлені у багатьох як прозових, так i поетичних фольклорних жанрах. Широке використання прийому перетворення пов'язане із віруваннями про безсмертя людської душі, а відтак і про їі перенесення до світу тварин і рослин, де вона набуває нового життя. Баладний жанр виявляється дуже показовим і плідним у цьому відношенні, оскільки фантастичному компонентові, чи як його йменував Ф. Колесса, «фантастичному первню» [Kolessa 1938 : 108] відводиться ключове місце у структурі баладних творів, а перетворення-метаморфози $\epsilon$ невід’ємною складовою фантастичних творів. Ф. Колесса присвятив також 
увагу окремим епізодам перетворення в баладах, які видалися йому найбільш показовими і промовистими [Kolessa 1970 : 109_163.]

Серед українських фольклористів перетвореннями, насамперед у баладному жанрі, цікавилися також М. Костомаров [Kostomarov 1994: 315], який здійснив спробу стратифікувати перетворення, і О. Дей, який запропонував грунтовне теоретичне аргументування залученню мотиву перетворення у народній баладі, зокрема українській, виходячи не 3 його функціонування у баладній традиції як залишку давніх вірувань, а як такого, що перебуває в активному вжитку на час виникнення тієї чи іншої балади [Dej 1986 : 20 - 21]. Дослідниця М. Качмар пропонує відрізняти функції перетворення-метаморфози у прозових фольклорних текстах від зразків народної балади саме у світлі бачення О. Дея, який надавав метаморфозам, відповідно, ідейно-художнього навантаження, бо трагізм людських взаємин підсилюється за рахунок введення до пересічних i буденних сюжетів надприродних явищ і алегоричної складової [Kachmar 2014: 741-747]. Нам така дослідницька позиція теж видається слушною.

Серед дослідників 3 південнослов'янського ареалу до цього питання зверталися практично всі більш і менш відомі дослідники-баладознавці, у фокусі їхньої уваги опинялися, проте, окремі різновиди перетвореньметаморфоз чи їхнє призначення у руслі розуміння баладного тексту. Так, Х. Крневич, С. Делич, Н. Мілошевич Джорджевич торкались цього питання у широкому контексті своїх баладознавчих студій, а, скажімо, сербська дослідниця К. Дарманович розглядала мотив перетворенняметаморфоз у світлі проблеми свого дисертаційного дослідження «Tipologija i funkcija ženskih likova u epskim pesmama Vukove zbirke» («Типологія і функція жіночих образів в епічних піснях збірки Вука Карджича», Новий Сад, 2016 р.), а С. Самарджія цікавилася перетвореннями-метаморфозами насамперед у зв'язку із народними традиційними уявленнями про змія [Samarųija 2012: 13 - 43] тощо.

Тепер варто детальніше зупинитися на показових прикладах функціонування мотиву перетворення-метаморфози, оскільки, попри загальну дидактичну настанову, 3 метою якої його залучено до цілого масиву баладних текстів, обставини, за яких він використовується, абсолютно різні. Нижче ми маємо за мету продемонструвати, на які саме типи метаморфоз натрапляємо у народних баладах південних 
слов\&аpos;ян. Ми, безперечно, будемо зупинятися лише на окремих епізодах функціонування мотиву перетворення, відстежуючи його на прикладах зі збірок балад окремих народів.

Так, на один 3 оригінальніших мотивів перетворення натрапляємо у боснійській народній баладі «Procvilila gora Šimširova» («Тужилаголосила пуща Шимширова»), де головною героїнею постає дівчина, що перетворилася на пущу, яка функціонує у творі як жива істота, наділена суто жіночою вдачею, зокрема, остання співчуває дівчині, що прийшла до iii кордонів, бо дівчина не знає, хто іiї суджений, хоч до дівчини-пущі приходили до неї свати. Дівчина-пуща описує дівчині іiі майбутнього нареченого: він має бути весь у золоті, із довгою білою бородою до поясу. Дівчина вирушає на пошуки нареченого, зустрічає свого брата, який теж у подібний спосіб описує їй іiі судженого, але навіть коли дівчина об\&apos;їздила цілий світ, їй не вдається його розшукати, вона у відчаї накладає на себе руки [60 najljepših balada Bošnjaka 2002 : 74].

Чи, наприклад, у болгарській баладі «Невяста-кошута» («Нареченалань»), спостерігаємо фантастичний образ нареченої. Гарна дівчинанаречена звертається до міського владики і літніх шанованих попів, аби вони запитали у попа Лазаря, чому він залишив свою люблячу наречену, чи не тому, що не дочекався від неї багатого посагу?

Лазар на це відповідає старцям, що у нього $є$ наречена, тільки дуже вона незвичайна, адже:

...денем е млада невеста, ... вдень вона молода наречена,

нощем е дива комута. вночі вона дивная лань.

Като сльнцето заходи, Коли сонце заходить,

хората в село улазат, люди у село заходять,

она из село излаза. вона із села тікає.

Кога се заран зазори, Коли зоря загорається,

хората из село излазат, люди із села йдуть,

а тя у село улази. а вона до села приходить.

Кога си дойде домака, До кого прийде додому,

бели и поли се роса, біла там видніється роса,

ситни и зъби се трева. дрібна і низька там трава [Българска народна

поезия и проза в седем тома. том IV: Народни балади $1982: 214]$.

Дуже часто натрапляємо на мотив перетворення-метаморфози як покарання. Промовистим прикладом безвинного покарання молодої дівчини може виступати боснійська народна балада «Majka Fatu rano budi» («Мати Фату раненько збудила»), де мати карає дочку Фату за те, 
що вона рано не встає, хутко до роботи не береться, квітучої рожі не зриває (народне вірування), вона перетворюється на холодне мармурове каміння. Особливо біль і жаль за втраченою дівчиною підсилюється деталями опису святкування свята Байрам, коли кожен брат повинен навідати свою сестру, а брату Фати тільки й залишається, що притулитися до холодного мармурового каміння, з очей якого, проте, витікають гіркі сльози, а 3 вуст вириваються жалісливі зітхання-питання про те, чи каміння тепер дбає про iii матір, наводить лад в її оселі, чи приносить свіжої води з криниці? [60 najljepših balada Bošnjaka 2002 : 89].

Зовсім іншим $є$ покарання за злочин, одним із таких злочинів $\epsilon$ перелюбництво. Так, у хорватській народній баладі «Preljubnica» (tragi

ni rasplet) («Перелюбниця» (трагічний фінал)) невірну дружину Анджелію Іво Задранин карає смертю, але ії вчинок видається настільки огидним і неприйнятним для народної моралі, що навіть після ï смерті відбуваються такі фантастичні перетворення-метаморфози:

Di je od nje kapja krvi pala, Де їі краплина крові впала,

Tи su resli trnji svakojaki, поросла земля колючим терном,

A di ona sama sebon pala, де вона безсила, мертва впала,

jezero se tote provalilo. озеро під землю провалилось [Delić 2011 : 121].

Ще жорстокіше карає Бог за убивство і намовляння. Промовистим прикладом може виступати сербська народна балада «Бог никоме дужан не остаје» («Бог ні перед ким не залишасться у боргу»). Підступна Павловиця зводить страшний наклеп на улюблену сестру свого чоловіку - добру і щиру Слицю, звинувачуючи ii у вбивстві спочатку сокола й коня, а потім свого маленького синочка. Насправді ж усі ці вбивства вона скоїла сама. Безперечно, останнє убивство залишити безкарним їі чоловік із братом не змогли і жорстоко покарали Єлицю страшною смертю. Бідолашна дівчина навіть не намагалася захищатися і смиренно прийняла мученицьку смерть. Але вбивцю Павловицю було покарано невиліковною тривалою хворобою i мученицькою смертю. Ї̈̈ не впускають церковні ворота, не приймає навіть сира земля. Цікаві перетворення-метаморфози подані у творі: коли змучена Павловиця просить убити їі так, як померла безневинна Єлиця, чоловік виконує прохання дружини, але відбувається диво: кожна крапля свіжої крові вбивці перевторюється на чортополох та кропиву, а на місці, де вона знаходить вічний спокій, стихійно виникає 
озеро 3 каламутною водою, ним пливуть жертви Павловиці [Милошевић-Ђорђевић 2001: 5].

За нечувану жорстокість і невдячність покарано і синів із сербської народної балади «Неблагодарни син» (в українському перекладі «Невдячні сини»). Мати дев'ятьох синів переживає страшенну драму: вона сама удовицею виховує дітей, одружила вже вісьмох синів, а коли вже останній, дев'ятий, замислив одружитися, він звертається до матері із такими словами:

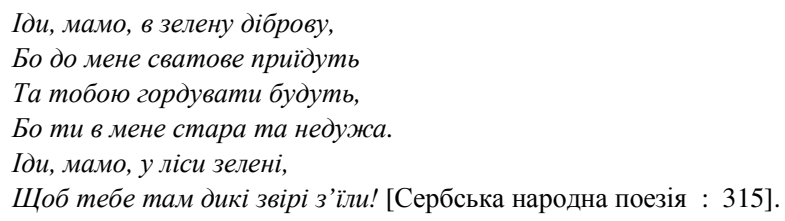

Віддана дітям мати не хоче заважати їхньому щастю і мовчки, ковтаючи сльози, вирушає до зеленого лісу, по дорозі зустрічає двох хлопців, які питають іï, куди вона йде така сумна, старенька розповідає їм свою трагічну історію.

Подорожні вислухали іï, тоді звернулися до неї, пропонуючи їй подивитися, що діється із ії синами і невістками. Далі наводиться картина у дусі народної моралі:

А як мати назад повернула:

Дев\&аров;ять синів, то дев\&аров;ять каменів,

А невістки - лютії гадюки,

А гадюки по каменях в\&аров;ються [Сербська народна поезія 1955 : 316].

У боснійських любовних народних баладах із соціальною складовою, йдеться про твори, де на заваді шлюбу між закоханими стають їхні батьки (переважно матері), у фінальній трагічній частині, де слухач стає свідком єднання закоханих лише після смерті, на тому, кращому світі, їхні душі перетворюються на яскраві і запашні квіти, чиї квіточки переплітаються між собою. Порівняймо для прикладу завершувальні рядки принаймні трьох боснійських балад із любовною тематикою:

- «Поруч із Мехо лозу посадовили, поруч із Фатою червону ружу, нехай лоза навколо ружі в'ється, як Мехо навколо своєї Фати» («Meho s majkom po Has-Bašči hoda» («Mexo із матір'ю по Хас-Башчі ходить»)) [60 najljepših balada Bošnjaka 2002: 246]

Там, де цвіла рум'яна ружа, - на могилі красуні Злати, і там, де виноградна лоза квітнула - на могилі Муйі, буйно ріс учора чорний терен, який не давав прекрасним 
рослинам зустрітися, а тепер лоза виноградна навколо ружі обгорнулася («Mujo gleda u mahali Zlatu») («Муйо бачить у кварталі Злату») [60 najljepših balada Bošnjaka 2002: 289]

Više glave Muje čelebije, - Вище за голову Муйі

ponikla je vinova lozica,oпустила голову виноградна лоза,

viš\&apos; Ajkune rumena ružica: вище Айкуни - рум'яна троянда:

sve se loza oko ruže vija, все лоза коло ружі в'ється,

kô Мujine ruke oko Ajke. як руки Муйі коло Айки.

(«Mujo gleda Ajkunu djevojku» («Муйо виглядає дівчину Айкуну») [60

najljepših balada Bošnjaka 2002 : 329]

На дивовижне і неочікуване перетворення у баладі, де наявна любовна проблематика, натрапляємо й у відомій сербській народній баладі «Сунце» («Сонце»). На своєрідний турнір викликає сонце зухвалу, але дуже гарну дівчину, яка стверджувала: «Сонце ясне, я за тебе краща!»:

Прокидайся, щойно засвітає,

Одягайся, як лиш можеш ліпше,

Та виходь, красуне, в чисте поле,

А я стану у сяйному небі,

Глянем одне одному ув очі,

То й побачим, хто з нас потемніс [Сербська народна поезія 1955 : 335].

Дівчина погодилася і прийшла, змагання розпочалося і тривало аж до неочікуваного фіналу, в якому і спостерігаємо фантастичні картини із перетвореннями:

Ліс зелений зів\&аров;янув від сония,

I криниия світла пересохла,

А краса дівоча не зів\&аров;яла, -

Тільки юнакові молодому

Серие молоде зів\&аров;яло в грудях,

Наче запахуща рожа-квітка [Сербська народна поезія 1955 : 335].

Лише зрідка у баладних творах наявний щасливий фінал, саме на нього натрапляємо у болгарській фантастичній народній баладі «Брат от сухо дърво» («Брат із сухого дерева»). Щире бажання дев’яти сестер мати хоча б одного брата і захисника здійснюється: вони вирушають до лісу i, знайшовши там сухе дерево, святково вбирають його, надаючи йому людської подоби:

зъбите му - два низа маниста, зуби його, як дві низки намиста, устата му - шекерна кутиа, вуста його - як коробочка иукру, очите му - две иръни череши, очі його - як дві вишні червоні, веждите му - морски пиявици. брови його - як п'явки морськії.

Але цього дівчатам видається замало, адже їхній брат абсолютно нездатний жити серед людей: у нього немає ні очей, щоб дивитися, ні рук, 
аби ними налити чаші червоного вина, і взагалі - він не живий, а вони так хотіли, що їхній брат став звичайною людиною. Тоді дівчата, не змовляючись, звернулися із щирою молитвою до Бога, який не зміг не відгукнутися, оскільки від сили їхнього голосу розірвалося небо, а від їхніх гірких сліз повінь уже на землі розпочалася! Бог не зміг залишатися байдужим до прохання дівчат і сталося неочікуване:

огай се е на Бога смилило, тоді Бог змилувався, та на дръво он душа сададе: послав дереву він душі людської: очи пройма, та си чаша виде, очі дав, щоб побачити чаму, ръце пройма, та чама прифана, руки дав, щоб чаму тримати, уста пройма, та си чаша напи. уста дав, щоб з чаши напитись [Българска народна поезия и проза в седем тома. том IV: Народни балади $1982: 412]$.

Зглянувся Бог і над бідолашною дівчиною Яною з болгарської балади «Сестра-кукувица» («Сестра-зозуля»), яка, намагаючись вилікувати свого пораненого і слабкого брата, вирушає на його прохання, аби набрати цілющої студеної води з Дунаю. Але, попри те, що вона дослухалась братових порад і виклала дорогу від шатра хворого брата Стояна до блакитного Дунаю і деревиною і камінням, ій так і не вдалося віднести братові рятівної води - вона заблукала на зворотньому шляху у гірських стежинах. Три дні блукала вона i три ночі, потім попросила Бога перетворити іï на маленьке пташеня, аби вона могла літати і шукати свого брата. Бог виконав іiі прохання і перетворив на зозулю - так вона і досі літає і шукає Стояна [Българска народна поезия и проза в седем тома. том IV: Народни балади $1982: 448]$.

Образ жінки, що перетворилася на зозулю, є доволі частовживаним у народній баладі. На нього натрапляємо, скажімо, у відомій сербській народній баладі «Чура у тамници» («Чура у темниці»). У цьому похмурому творі ув\&аров;язнений Чура, аби нагодувати сокола, кришить свої пальці, а напуває птаха своїми гіркими слізьми, сокіл питає його згодом, навіщо він це робить, чи для того, щоб його продати, а чи для того, щоб його із дорученням послати? Чура відповідає йому, що він хоче його у дорогу далеку відправити, у дорогу до свого двору.

Чура на це йому відповідає, що він якраз напередодні вночі літав над його двором і спостерігав там таку сумну картину:

Двір твій заглушило полинами,

Серед двору стоїь сухе древо,

На тім древі кують три зозулі: 
Одна кує, кує й не змовкає,

Друга кує звечора і зрання,

Третя кує, як лягає спати [Сербська народна поезія 1955 : 301].

Далі у баладі подається розшифрування символічних образів зозулі, про них дізнаємось від самого Чури-темничарина, він розповів про це соколові перед тим, як із душею розпрощатися:

Та, щуо кує, кує й не змовкає, -

Та то ж моя остаріла ненька,

Та, щуо кує звечора $і$ зрання, -

Та то ж мила сестра моя рідна;

Та, шуо кує, як лягає спати, -

То ж, соколе, моя вірна жінка [Сербська народна поезія 1955: 301].

Але далеко не завжди Бог виявляється таким поблажливим до людських прохань. Тому незрідка у баладних творах ми спостерігаємо і перетворення-метаморфози відповідно до засад моралі і уявлень про справедливість. Так, у болгарській народній баладі «Дете от камък» («Дитина 3 каменю») Бог, спочатку дослухаючись до сліз і гарячих молитов бездітної Єнки, підказує їй шлях до довгоочікуваного материнства: вона повинна піти до моря, на узбережжі морському знайти білий мармуровий камінь, скупати його у чистій морській воді, як дитинку, загорнути його згодом у золоті пелюшки і покласти до золотої просторої люльки, колисати його довгих дев'ять місяців, а після цього очікувати на диво. Снка все так і зробила, через указаний термін камінь перетворився на немовлятко. Але, коли Єнка, звертаючись до служників і служниць, наказала їм, скориставшись Божою ласкою, зібрати повні комори морського піску і повні діжки морської води, щоб вони перетворилися на майно для її дитинки - нового господаря оселі і спадкоємця - Бог карає іiї за жадібність і зловживання його щедрістю:

Кога са назад повърна,Коли назад повернулася-озирнулася,

и във люлчица погледна -до люльки зазирнула -

дете на камък станало.Дитина знову каменем стала [Българска народна поезия и проза в седем тома. том IV: Народни балади $1982: 511]$.

Ще один важливий різновид перетворень-метаморфоз пов\&арок;язаний iз переходом із світу мертвих до світу живих, тобто йдеться про перетворення мертвої людини на живу. Найчастіше мешканець того світу повертається до світу живих, аби побачитися із рідними і близькими. Яскравим прикладом може виступати сербська народна балада «Браћа и сестра» («Браття і сестра»). Сестра, що вийшла заміж за бана 3-за моря, й 
сама не знала, що немає більше серед живих жодного з ії дев'яти братів, адже їх забрала чума. Сестра Єлиця усе чекає дня, коли ії навідають брати, а вони все до неї не приїжджають. Тоді над бідолашною дівчиною змилостивився Господь і послав двох янголів на землю і дав їм такий наказ:

Ідіть, мої ангели, на землю,

До білого гробу Йован-бега,

Йован-бега - найменшого брата,

Натхніть його своїм живим духом,

Сотворіть йому коня живого,

Сотворіть з землиці паляниці,

3 покрова дарів сестрі наріжте,

Справте його до сестри у гості. [Сербська народна поезія 1955 : 286].

Дивовижне перетворення відбулося. Брат прийшов до сестри, остання зраділа, лише здивувалася, чому іiі брат почорнів лицем, але Йован відповів, що це тому, що він разом із братами будував їм дев' ять будинків.

Проте, згодом сестра дізналася, що брати iï померли, бо запримітила нові могили на цвинтарі, тоді вона вирушила до матері у двір, а там почула, як кує зозуля сива, а то була не зозуля, а ії старенька мати, яка спочатку прийняла її за морію, яка зморила дев'ятьох її синів, а тепер прийшла уже за нею. Але Єлиця вийшла наперед, і матір побачила свою дочку, вони обнялися, закували, як зозулі, і обидві мертві впали на землю.

Привертає увагу конструкція балади - постійні переходи від реалій цього і сього світу, а також численні перетворення - мертвих на живих, i навпаки, у фінальній частині - останній перехід і останнє перетворення: брат повертається до домовини (світу мертвих), рівновага між світами відновлюється шляхом відходу до світу мертвих матері і дочки. Перед цим вони зустрічаються, зустріч відбувається біля воріт чи на порозі будівлі, або коли дочка перетинає поріг, заходить всередину дому, чи за межами будівлі, тоді мати виходить назустріч доньці; зауважимо, що незрідка місце зустрічі взагалі не наводиться, локус - не окреслюється.

Підсумовуючи, зробимо спроби стратифікувати, безперечно, лише у загальних рисах, різновиди мотивів перетворення, які, як найбільш промовисті, представлено у підрозділі. Так, можна виділити наступні:

- перетворення-персоніфікація: неживий предмет функціонує як жива істота, найчастіше як людина (наприклад, «Procvilila gora Šimširova» («Тужила-голосила пуща Шимширова»); 
Компаративні досліАження слов'янських мов і Аітератур. 2019. Випуск 35

- перетворення нареченої на тварину, образ нареченої-тварини: наречена перетворюється на олениху, на лань чи на іншу гарну гордовиту тварину («Невяста-кошута» («Наречена-лань»);

- перетворення-покарання безневинної істоти: світла і чиста істота зазнає покарання, на яке не заслуговує, найчастіше таке покарання нагадує наврочення і йде від близьких людей («Majka Fatu rano budi» («Мати Фату раненько збудила»);

- перетворення-покарання за подружню зраду, прикладом може виступати народна балада «Preljubnica (tragi

- ni rasplet) («Перелюбниця» (трагічний фінал));

- перетворення-покарання за невдячність, як у народній баладі «Наблагодарни син» («Невдячні сини»);

- перетворення-покарання за вбивство i намовляння. Яскравим прикладом може виступати народна балада «Бог никоме дужан не остаје» («Бог ні перед ким не залишається у боргу»);

- перетворення душ закоханих на прекрасні квіти і трави («Meho s majkom po Has-Bašči hoda» («Mexo із матір'ю по Хас-Башчі ходить»); "Mujo gleda u mahali Zlatu» (“Муйо бачить у кварталі Злату»); «Mujo gleda Ajkunu djevojku» («Муйо виглядає дівчину Айкуну»); «Сунце» («Сонце») тощо);

- перетворення неживих предметів на дитину як нагорода безплідній матері або родині, в якій немає дітей чоловічої статі, немає спадкоємців. У таких баладах варіюються фінальні епізоди - від оптимістичних («Брат от сухо дърво» («Брат із сухого дерева») до трагічних («Дете от камък» («Дитина з каменю»);

- перетворення дівчат і жінок на птахів, які шукають своїх близьких чи тужать за ними («Сестра-кукувица» («Сестра-зозуля»); «Чура у тамници» («Чура у темниці»);

- перетворення мертвих героїв на живих. Зазвичай подібні перетворення відбуваються, аби забезпечити побачення із близькими родичами, що тужать за померлими, мріють про зустріч із ними («Браћа и сестра» («Браття і сестра»). 


\section{REFERENCES:}

1. Blgarska narodna poezija i proza v sedem toma (1982). Tom IV: Narodni baladi. Sostavitel Stojanka Bojadzhieva, 800 p. (in Bug.)

2. Dej O.I. (1986) Ukrainska narodna balada, pp. 20 - 21 (in Ukr.)

3. Delić S. (2011) Silva Hispanica. Komparativna studija o žanru balade u modernoj hrvatskoj i španjolskoj usmenoj tradiciji, p. 121. (in Croat.)

4. M.Metamorfoza $v$ ukrainskih narodnych baladach: genetychno-funkcionalnyj aspect. Narodoznavchi zoshyty, no 4, pp. 741-74. (in Ukr.)

5. Kolessa F. (1938) Ukrainska usna slovesnist: zagalnyj oglad i vybir tvoriv, no $1-4$ (22)), p. 108. (in Ukr.)

6. Kolessa F. (1970) Balada pro dochku-ptashku v slovjanskij narodnij poeziji, pp. 109 - 163. (in Ukr.)

7. Kostomarov N. (1994) Slavjanskaja mifologija : vybrani praci z folklorystyki i literaturoznavstva, p. 315. (in Ukr.)

8. Miloshevich-Dzhordzevich N. (2001) Srpske narodne epske pesme i balade, p. 5. (in Serb.)

9. Samarųija S. (2012) Ko se krije ispod zmijskog svlaka? Metamorfoze u žanrovskom sistemu. Guje i jakrepi, pp. 13 - 43. (in Serb.)

10. Serbska narodna poezija (1955), p. 347. (in Ukr.)

11. 60 najljepših balada Bošnjaka (2002), p. 600. (in Bosn.)

Колбишева $\boldsymbol{C}$. к.пед.н., Національний інститут освіти (Республіка Білорусь) Kolbysheva $S$. Candidate of pedagogics, Institution National Institute of Education (Republic of Belarus)

\section{ХУДОЖЕСТВЕННАЯ КОММУНИКАЦИЯ: ВЗАИМОДЕЙСТВИЕ СТРУКТУРНЫХ КОМПОНЕНТОВ}

\section{ARTISTIC COMMUNICATION: THE INTERACTION OF THE STRUCTURAL COMPONENTS}

У статті актуалізовано проблема комунікаиії та ї̈ зв'язку з різними сочіокультурними формами. Розглянуто різні аспекти комунікачії. Проаналізовано місие і роль художньої комунікачії як специфічної форми суспільної свідомості. Виділено об'єктивні і суб'єктивні чинники, щзо впливають на процес художньої комунікації; в якості провідного чинника художньої комунікації визначено фактор 